\title{
Selection of some faba bean segregation genotypes in contrasting environments
}

\author{
Ehab. H. El-Harty \\ Legume Research Section, Field Crops Research Institute, Agricultural Research Center, Giza 12619. Egypt. \\ Legume Research Unit., Plant Production Department, College of Food and Agricultural Sciences, King Saud \\ University, Riyadh, Saudi Arabia \\ Corresponding author: ehabelharty@gmail.com
}

\begin{abstract}
Bulk selection method was used among six faba bean crosses during $\mathrm{F}_{3}$ and $\mathrm{F}_{4}$ generations under drought and/or non-drought conditions. Four methods ( $M_{1}$, was grown under drought in $F_{3}$ and $F_{4}, M_{2}$, was grown under drought in $F_{3}$ and non- drought in $F_{4}, M_{3}$, was grown under non-drought in $F_{3}$ and drought in $F_{4}$ and $\mathrm{M}_{4}$, was grown under non-drought in $\mathrm{F}_{3}$ and $\mathrm{F}_{4}$ ) were formed from each cross in $\mathrm{F}_{5}$ and evaluated in two open field experiments (under drought and non-drought conditions). The experiments were planted in split plot design with crosses in main plots and selection methods in sup plots. Highly significant differences among crosses and methods and their interactions were reported by combined analysis of both environments. Drought harmful faba bean traits and seed yield decreased from 53.5 to $74.4 \%$. Under drought stress, $\mathrm{M}_{1}$ selection method produced the highest seed yield and crosses of Hassawi2 by Luz and by TW had the highest seed yield/plant 15.4 and 13.3g, respectively. On the other side M4 was the best selection method for non-stress conditions and TW x Hassawi2, TW x Hassawi3 and Luz x Hassawi3 recorded highest seed yield 41.7, 37.9 and $37.3 \mathrm{~g}$, respectively. High values of PCV, GCV for $\mathrm{M}_{4}$ under non-drought suggested that bulk selection under favorite conditions increased the phenotypic and genotypic variance, particularly under same conditions. heritability values were higher for each selection method under conditions that breed for it indicating that, selected high yields under specific condition may be combined with sensitive alleles to other condition. Plants exposed to different conditions of drought and non-stress during the previous generations $\left(\mathrm{M}_{2}\right.$ and $\left.\mathrm{M}_{3}\right)$ were had less response to environments changes with low seed yield.
\end{abstract}

Abbreviations: PCV-phenotypic coefficient of variation, GCV-Genetic coefficient of variation, Broad sense heritability.

Keywords: faba bean, selection, drought, genetic variability, heritability.

\section{Introduction}

Faba bean (Vicia faba L.) improvement programs under drought area aim to select genotypes showing high and stable yields. Water stress is a main factor limiting faba bean yields and as other crops. Drought is water deficit, leading to a significant reduction in yield, it is widely considered to be the most important environmental constraints to crop productivity, furthermore the climatic-change models predict that, yield variability will increase with increasing in drought (Marsh 1996, Singh, 1995, Borlaug and Dows well 2005). Drought may occur when crops are planted at the beginning of a dry season (terminal) or intermittent drought is due to climatic patterns of sporadic rainfall that cause intervals of drought at varying intensities (intermittent drought) (Ludlow and Muchow 1990).

Food legumes are ideal crops for simultaneously achieving three developmental goals in targeted population reducing poverty, improving human health and nutrition, and enhancing ecosystem resilience. Faba bean (Vicia faba L.) is one of oldest crops it grows for feed and food. Faba bean plants is well-known to be unstable in yield where it gives high productive under favorable conditions, but it is sensitive to drought stress Amede and Schubert 2003, Khan et al., 2007,Abdellatifet al. 2012 and Ammar, et al. 2014 also, wet conditions, Grashoff 1990; Keneni et al., 2001. This yield instability and low genetic heritability leads faba bean breeders to exert great efforts to develop cultivars that are more suitable and adaptable to environmental conditions, particularly drought whose occurrence is unpredictable. Which selection to improve crop production within a specific agroecological environment may be lead to the risk of exposure of plants to inappropriate conditions such as waves of hot heat or drought also develop genotype to specific target or area may lead to decrease the adaption of genotype. Otherwise, selection for wide adapted variety is dealing with the problem of identifying variety able to cope with condition variation. However Blum (1984) suggested that genotypes that show better performance under hostile environments generally possess some unidentified physiological attributes of tolerance to environmental stresses in good conditions. But progress in the development of drought-tolerant faba bean cultivars has been slow, mainly due to large seasonal variations in the intensity of drought stress, the timing of its arrival and a lack of efficient 
screening techniques (Turner et al., 2001; Stoddard et al., 2006 and Lande 2009). Selection strategies can range from the simplest method to recurrent selection, or more complex schemes (Dawson and Goldringer 2012). Using mixtures faba bean populations can be used to develop adapted populations poor environment (Terzopouloset al. 2008). Where crop gene-pools have the ability to modify their crop performance in response to changing environmental circumstances (Allard 1988) measuring genotype by environment interactions are also important to determine an optimum breeding strategy for releasing cultivars with adequate adaptation to target environments (Fox et al. 1997)

This study was conducted to compare the four selection methods under different environments in early generations on faba bean performance and variability of six crosses in late generation.

\section{Material and Methods}

This investigation was conducted in open field of Derab Research and Agricultural Experiment Station,
College of Food and Agriculture Sciences, King Saud University, Riyadh, Kingdom of Saudi Arabia during three succeed seasons of 2011-2014. Bulk selection method was done on six faba bean $F_{2}$ populations (crosses between Luz and Triple White with three local cultivars, Hassawi 1, Hassawi 2 and Hassawi 3). Seeds of each population were divided to grow under two conditions; drought stress and nondrought stress in $F_{3}$ during 2011/2012 season. All $\mathrm{F}_{3}$ plants of each population, from stress and nonstress conditions were harvested separately and only 150 seeds were selected randomly from each group to grow in next generation under drought stress and another 150 seeds to grow under non- stress. Then the same processes repeated in $\mathrm{F}_{4}$ generation. Finally in $\mathrm{F}_{5}$; four selection methods $\left(\mathrm{M}_{1}\right.$, selected under drought in $\mathrm{F}_{3}$ and $\mathrm{F}_{4} ; \mathrm{M}_{2}$, selected under drought in $\mathrm{F}_{3}$ and non- drought in $\mathrm{F}_{4} ; \mathrm{M}_{3}$, selected under nondrought in $\mathrm{F}_{3}$ and drought in $\mathrm{F}_{4}$ and $\mathrm{M}_{4}$; selected under non-drought in $\mathrm{F}_{3}$ and $\mathrm{F}_{4}$ ) were take shape for each populations. The description of the four selection methods are presented in Fig. 1.

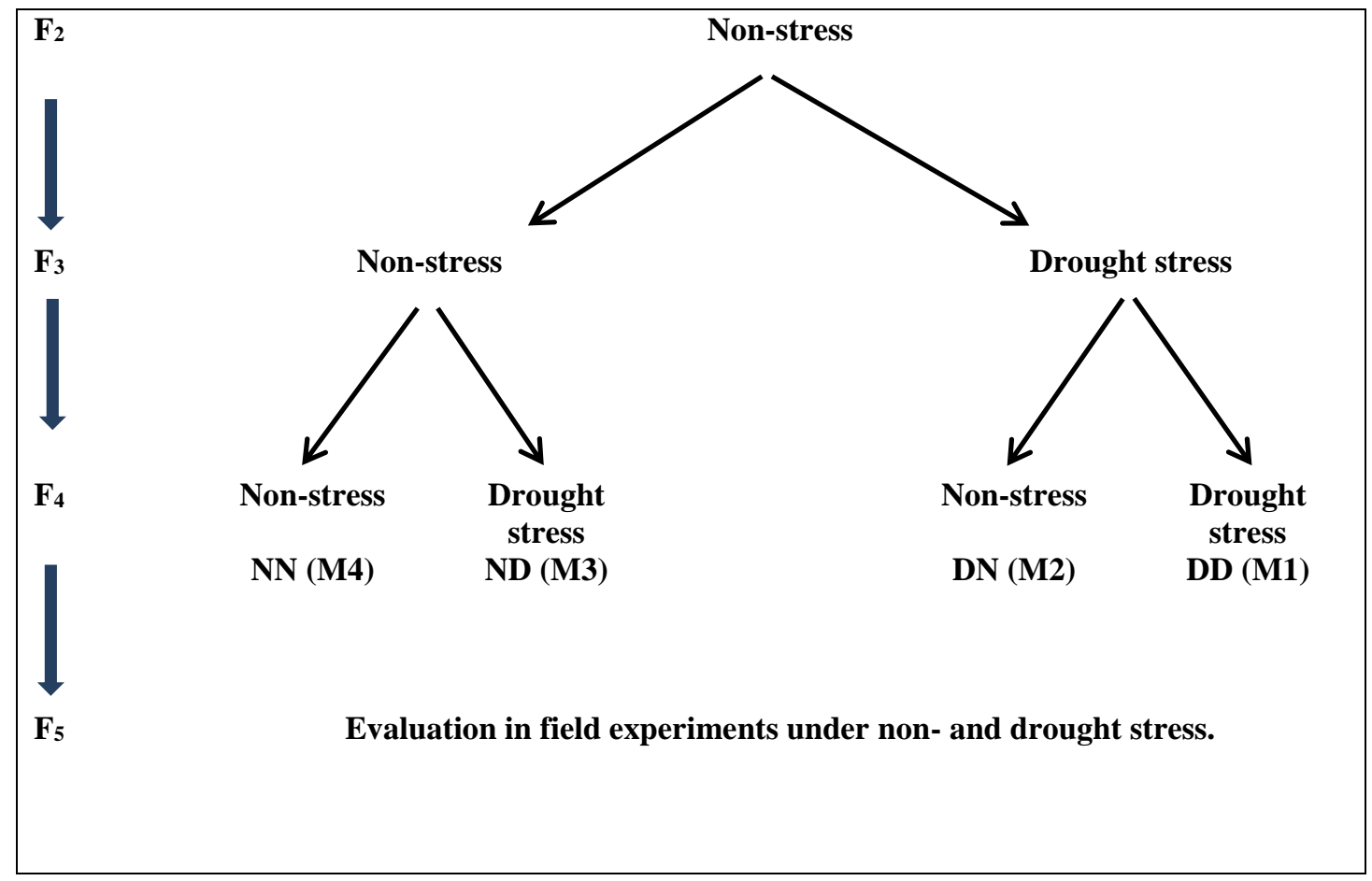

Figure 1.Description of the four selection methods

Two field independent experiments were carried out the first one under drought stress and second one under non- stress conditions to evaluate the six $\mathrm{F}_{5}$ population that selected by the four methods during 2013/14 season. The water stress was applied in this investigation by irrigation when an amount of evaporated water from the 'class A pan' evaporation reached $125 \mathrm{~mm}$ (drought stress), $50 \mathrm{~mm}$ (nondrought stress). The experiments were designed as split plot trial with three replications. The six crosses were randomly assigned for main plots and the four selection methods were placed in sup plots. The experimental plot consisted of 2 rows spaced $50 \mathrm{~cm}$ apart with 3 meters long. Seeds take place on hill with $15 \mathrm{~cm}$ apart. Sowing date was in first week of November in each season. Cultural practices were applied as recommended. At maturing, all healthy plants per experiment plots were harvested separately 
to measure yield and its components (plant height, no. of branches, pods, seeds, seed yield/plant and 100 -seed weight.The average data collected from each experiment were analyzed separately and combined of the two locations using Fisher's analysis of variance technique. Duncan test at $5 \%$ probability was used to compare the differences among treatments means; according to Steel et al., 1997.

The data were then separated by progression method and subjected to variance analysis following a Randomized Complete Block design, and estimates for the variance components were obtained according to Sharma (1998), genotypic variance between crosses $\left(\sigma^{2} \mathrm{~g}\right)=$ (MSgenotype - MSerror $) / \mathrm{r}$ and Phenotypic variance $(\sigma 2 \mathrm{p})=$ MSgenotype/r. Broadsense heritability between crosses was calculated as the ratio of genotypic variance to the phenotypic variance $\left(h^{2}=\sigma^{2} g / \sigma^{2} p\right)$ according to Allard (1999). Genetic coefficient of variationG.C.V.\% $=100 *$ $\left(\sqrt{\sigma^{2} g} /\right.$ mean $)$, phenotypic coefficient of
variationP.C. V. $\%=100 *\left(\sqrt{\sigma^{2} \mathrm{p}} /\right.$ mean $)$ were calculated as formula proposed by Singh and Chaudhary (1985)

\section{Results and discussions}

The analysis of variance for combined of both environments (Table 1) showed the significant of all sources of variance for all traits studied except methods in pods/plant and interaction of crosses by environments for plant height. Environments recorded the highest variance followed by crosses in some cases. However the interactions between crosses and methods were found to be significant in all cases. Selection methods had highly significant mean squares for pods, seeds and seeds/pod indicated that existence of variability among genotypes but the selection methods successfully were increased the variability.

Table 1.Combined Analysis of variance for the traits traits studies of six crosses under drought and non-stress conditions

\begin{tabular}{|c|c|c|c|c|c|c|c|c|c|c|c|c|c|}
\hline \multirow[t]{2}{*}{ SO V } & \multirow[t]{2}{*}{ df } & \multicolumn{2}{|c|}{ Plant height } & \multicolumn{2}{|c|}{$\begin{array}{l}\text { No. of } \\
\text { branches } \\
\text { /plant }\end{array}$} & \multicolumn{2}{|c|}{$\begin{array}{l}\text { No. of pods } \\
\text { /plant }\end{array}$} & \multicolumn{2}{|l|}{$\begin{array}{l}\text { No. of seeds } \\
\text { /plant }\end{array}$} & \multicolumn{2}{|c|}{100 seed weight } & \multicolumn{2}{|c|}{ Seed yield/ plant } \\
\hline & & MS & $\%$ & MS & $\%$ & MS & $\%$ & MS & $\%$ & MS & $\%$ & MS & $\%$ \\
\hline Environment(E) & 1 & $24987.7 * *$ & 95.4 & $28.4 * *$ & 70.6 & $4094.9^{* *}$ & 88.8 & $25875.4 * *$ & 92.6 & $9091.6^{* *}$ & 69.1 & $18514.1 * *$ & 95.5 \\
\hline $\mathbf{R}(\mathbf{E})$ & 4 & 44.1 & 0.2 & 0.9 & 2.2 & 36.1 & 0.8 & 38.2 & 0.1 & 65.0 & 0.5 & 29.3 & 0.2 \\
\hline Crosses (C) & 5 & $554.9^{* *}$ & 2.1 & $2.2 * *$ & 5.5 & $180.9^{* *}$ & 3.9 & $747.3 * *$ & 2.7 & $1345.6^{* *}$ & 10.2 & $149.4 * *$ & 0.8 \\
\hline $\mathbf{E} \times \mathbf{C}$ & 5 & $21.0 \mathrm{~ns}$ & 0.1 & $3.6^{* *}$ & 9.0 & $181.7^{* *}$ & 3.9 & $685.6^{* *}$ & 2.5 & $800.5^{* *}$ & 6.1 & $206.9^{* *}$ & 1.1 \\
\hline Error & 20 & 28.2 & 0.1 & 0.5 & 1.2 & 4.59 & 0.1 & 11.3 & 0.0 & 58.3 & 0.4 & 8.7 & 0.0 \\
\hline Methods (M) & 3 & $102.0^{*}$ & 0.4 & $1.1 * *$ & 2.7 & $2.1 \mathrm{~ns}$ & 0.0 & $83.1 *$ & 0.3 & $381.3 * *$ & 2.9 & $94.5 * *$ & 0.5 \\
\hline $\mathbf{E} \times \mathbf{M}$ & 3 & $201.3^{* *}$ & 0.8 & $1.0^{* *}$ & 2.5 & $32.8^{* *}$ & 0.7 & $184.9^{* *}$ & 0.7 & $542.4 * *$ & 4.1 & $235.7^{* *}$ & 1.2 \\
\hline $\mathrm{C} \times \mathrm{M}$ & 15 & $100.3^{* *}$ & 0.4 & $1.7^{* *}$ & 4.2 & $41.7 * *$ & 0.9 & $142.5^{* *}$ & 0.5 & $360.9 * *$ & 2.7 & $60.1 * *$ & 0.3 \\
\hline $\mathbf{E} \times \mathbf{C} \times \mathbf{M}$ & 15 & $110.1^{* *}$ & 0.4 & $0.6^{* *}$ & 1.5 & $31.9^{* *}$ & 0.7 & $147.5^{* *}$ & 0.5 & $420.7 * *$ & 3.2 & $72.6 * *$ & 0.4 \\
\hline Error & 72 & 31.2 & 0.1 & 0.2 & 0.5 & 5.4 & 0.1 & 24.0 & 0.1 & 90.5 & 0.7 & 10.8 & 0.1 \\
\hline
\end{tabular}

*, ** Significant at 0.05 and 0.01 probability level, respectively, ns non-significant

Decrease as a result of drought stress, extended to include all faba bean traits beginning of plant height and number of branches where recorded less influential than number of seeds and pods and yield/plant, which severely affected by drought (Table 2). The reduction in seed yield/plant among populations ranged from 53.5 for Luz x Hassawi 2, to $74.4 \%$ for TW $x$ Hassawi 3 with an average of $65.1 \%$. Crosses of the local cultivar Hassawi2 with the introduced genotypes Luz and TW had the highest seed yield/plant 15.4 and $13.3 \mathrm{~g}$, respectively under drought stress. This may be due to adaptability and drought tolerance of Hassawi 2 and this result is strengthening the previous results for Ammar et al., 2014.TW X Hassawi 2 confirmed its yield potentiality recording the highest seed yield/plant $41.7 \mathrm{~g}$ and 27.5 under non-stress and overall environments, respectively followed by TW $\mathrm{x}$ Hassawi 3 and Luz x Hassawi 3 with mean values of $37.9 \& 37.3 \mathrm{~g}$ and $23.8 \& 23.7 \mathrm{~g}$ under non-stress and overall, respectively. TW x Hassawi 2 was higher in number of pods and seeds while Luz crosses had taller plants and heavier seed index (100seed weight). The superior of this cross in most traits indicated that to reach to high seed yield a combination of characteristics is needed or no single trait was adequate to improve yield in drought stress. Data indicated that Luz increased the plant height and seed index while TW increased number of pods and seeds/plant in their crosses in both conditions. This investigation presented the wide variation in drought tolerance among faba bean genotypes. Supporting evidences were reported by many researchers (Mwanamwenge et al., 1998, Frahm et al., 2004, Abdellatif et al., 2012, Yahia et al., 2012, Khan et al., 2010). 
Table 2. Mean performance of the six faba bean populations under drought stress non-drought stress and combined analysis

\begin{tabular}{|c|c|c|c|c|c|c|c|}
\hline Cross & Condition & $\begin{array}{l}\text { Plant } \\
\text { height } \\
(\mathrm{cm})\end{array}$ & $\begin{array}{l}\text { No. of } \\
\text { branches } \\
\text { /plant }\end{array}$ & $\begin{array}{l}\text { No. of pods } \\
\text { /plant }\end{array}$ & $\begin{array}{l}\text { No. of } \\
\text { seeds / plant }\end{array}$ & $\begin{array}{l}100 \text { seed } \\
\text { weight }(g)\end{array}$ & $\begin{array}{l}\text { Seed yield/ } \\
\text { plant (g) }\end{array}$ \\
\hline \multirow{3}{*}{ Luz x Hassawi 1} & Drought & $58.1 \mathrm{DE}$ & $3.4 \mathrm{~A}-\mathrm{D}$ & $7.3 \mathrm{E}$ & $19.0 \mathrm{FG}$ & 63.1 BCD & $11.9 \mathrm{EF}$ \\
\hline & Nondrought & $82.3 \mathrm{~B}$ & $3.7 \mathrm{AB}$ & $13.5 \mathrm{D}$ & $36.6 \mathrm{E}$ & $85.3 \mathrm{~A}$ & $30.9 \mathrm{CD}$ \\
\hline & Combined & $70.2 \mathrm{~b}$ & $3.5 \mathrm{ab}$ & $10.4 \mathrm{~d}$ & $27.8 \mathrm{e}$ & $74.2 \mathrm{a}$ & $21.4 \mathrm{~cd}$ \\
\hline \multirow{3}{*}{ Luz x Hassawi 2} & Drought & $66.4 \mathrm{C}$ & $3.7 \mathrm{AB}$ & $9.1 \mathrm{E}$ & $23.8 \mathrm{~F}$ & $65.2 \mathrm{BC}$ & $15.4 \mathrm{E}$ \\
\hline & Nondrought & $94.3 \mathrm{~A}$ & $3.5 \mathrm{ABC}$ & $14.2 \mathrm{D}$ & $38.3 \mathrm{DE}$ & $87.2 \mathrm{~A}$ & $33.1 \mathrm{BC}$ \\
\hline & Combined & $80.3 \mathrm{a}$ & $3.6 \mathrm{a}$ & $11.6 \mathrm{~cd}$ & $31.0 \mathrm{~cd}$ & $76.2 \mathrm{a}$ & $24.3 \mathrm{~b}$ \\
\hline \multirow{3}{*}{ Luz x Hassawi 3} & Drought & $55.2 \mathrm{E}$ & $2.4 \mathrm{D}$ & $6.1 \mathrm{E}$ & $16.9 \mathrm{G}$ & $60.8 \mathrm{BCD}$ & $10.1 \mathrm{~F}$ \\
\hline & Nondrought & $82.9 \mathrm{~B}$ & $3.8 \mathrm{AB}$ & $14.9 \mathrm{CD}$ & $42.7 \mathrm{CD}$ & $89.6 \mathrm{~A}$ & $37.3 \mathrm{AB}$ \\
\hline & Combined & $69.1 \mathrm{~b}$ & $3.1 \mathrm{ab}$ & $10.5 \mathrm{~d}$ & $29.8 \mathrm{de}$ & $75.2 \mathrm{a}$ & $23.7 \mathrm{bc}$ \\
\hline \multirow{3}{*}{ TW x Hassawi 1} & Drought & $64.4 \mathrm{CD}$ & $3.1 \mathrm{BCD}$ & $7.9 \mathrm{E}$ & $21.7 \mathrm{FG}$ & $58.4 \mathrm{CD}$ & $12.5 \mathrm{EF}$ \\
\hline & Nondrought & $88.6 \mathrm{AB}$ & $4.1 \mathrm{AB}$ & $18.0 \mathrm{BC}$ & $46.5 \mathrm{C}$ & $61.1 \mathrm{BCD}$ & $28.1 \mathrm{D}$ \\
\hline & Combined & $76.5 \mathrm{a}$ & $3.6 \mathrm{a}$ & $12.9 \mathrm{bc}$ & $34.1 \mathrm{bc}$ & $59.7 \mathrm{~b}$ & $20.3 \mathrm{~d}$ \\
\hline \multirow{3}{*}{ TW x Hassawi 2} & Drought & $53.9 \mathrm{E}$ & $2.4 \mathrm{D}$ & $7.6 \mathrm{E}$ & $21.8 \mathrm{FG}$ & $64.4 \mathrm{BC}$ & $13.3 \mathrm{EF}$ \\
\hline & Nondrought & $82.1 \mathrm{~B}$ & $4.3 \mathrm{~A}$ & $27.8 \mathrm{~A}$ & $64.6 \mathrm{~A}$ & $64.8 \mathrm{BC}$ & $41.7 \mathrm{~A}$ \\
\hline & Combined & $68.0 \mathrm{~b}$ & $3.3 \mathrm{ab}$ & $17.7 \mathrm{a}$ & $43.2 \mathrm{a}$ & $64.6 \mathrm{~b}$ & $27.5 \mathrm{a}$ \\
\hline \multirow{3}{*}{ TW x Hassawi 3} & Drought & $58.5 \mathrm{CDE}$ & $2.4 \mathrm{CD}$ & $7.4 \mathrm{E}$ & $19.0 \mathrm{FG}$ & $51.8 \mathrm{D}$ & $9.7 \mathrm{~F}$ \\
\hline & Nondrought & $84.5 \mathrm{~B}$ & $3.4 \mathrm{~A}-\mathrm{D}$ & $20.8 \mathrm{~B}$ & $54.3 \mathrm{~B}$ & $71.0 \mathrm{~B}$ & $37.9 \mathrm{AB}$ \\
\hline & Combined & $71.5 \mathrm{~b}$ & $2.9 \mathrm{~b}$ & $14.1 \mathrm{~b}$ & $36.7 \mathrm{~b}$ & $61.4 \mathrm{~b}$ & $23.8 \mathrm{bc}$ \\
\hline
\end{tabular}

Mean values sharig the same case letter do not differ significantly at P 0.05 .

The mean performance of four selection methods under both drought stress and non-drought stress and their interactions are presented in Table 3. Selection method $\left(\mathrm{M}_{1}\right)$ proved its ability to select drought tolerance plants with low responses or reduction in all traits followed by $\mathrm{M}_{2}$ and $\mathrm{M}_{3}$. Faba bean plants bred by $M_{1}$ produced $29 \%$ higher seed yield than plants of method 4 (bred under well conditions constantly) under drought stress conditions.

Estimates of $\mathrm{M}_{4}$ plants for all traits were the lowest than other methods under drought conditions indicated that, plants selected from well conditions were highly sensitive to drought. Ceccarelli et al., 1992 results suggested that the alleles controlling high grain yield in low-yielding conditions are at least partially different from those controlling high grain yield in high-yielding conditions. Therefore, selection of high-yielding environments is expected to produce a negative response in low-yielding environments. This may explain why crop varieties bred under high-yielding conditions failed to have an impact in low-yielding agricultural systems.

Reduction in seed yield due to grow under stress conditions ranged from 73.5 and $55.5 \%$ for $\mathrm{M}_{4}$ and $\mathrm{M}_{1}$, respectively detected that $\mathrm{M}_{1}$ produced high drought tolerant plants, but the highest yield (40.0g) produced by $\mathrm{M}_{4}$ under well conditions followed by $\mathrm{M}_{3}$ and $\mathrm{M}_{1}$ (34.7 and 33.7g, respectively).This means that selection high seed yield genotype under favorable environment may be combined with selection sensitive alleles to drought stresses. $\mathrm{M}_{2}$ and $\mathrm{M}_{3}$ plants were in-between without any superior in both environments.

Table 3. Mean values of the selection methods under drought stress, non- drought stress and their interaction.

\begin{tabular}{|c|c|c|c|c|c|c|c|}
\hline $\begin{array}{l}\text { Selection } \\
\text { method }\end{array}$ & Condition & $\begin{array}{l}\text { Plant } \\
\text { height } \\
(\mathrm{cm})\end{array}$ & $\begin{array}{l}\text { No.of } \\
\text { branches } \\
\text { /plant }\end{array}$ & $\begin{array}{c}\text { No. of } \\
\text { pods /plant }\end{array}$ & $\begin{array}{l}\text { No. of } \\
\text { seeds } \\
\text { /plant }\end{array}$ & $\begin{array}{c}100 \text { seed } \\
\text { weight }(\mathrm{g})\end{array}$ & $\begin{array}{c}\text { Seed } \\
\text { yield/ } \\
\text { plant (g) }\end{array}$ \\
\hline \multirow{3}{*}{$\mathrm{M}_{1}$} & Drought & $58.2 \mathrm{C}$ & $2.7 \mathrm{DE}$ & $8.2 \mathrm{BC}$ & $23.5 \mathrm{C}$ & $64.5 \mathrm{CD}$ & $15.0 \mathrm{D}$ \\
\hline & Nondrought & $87.6 \mathrm{~A}$ & $4.0 \mathrm{~A}$ & $17.4 \mathrm{~A}$ & $46.5 \mathrm{AB}$ & $73.8 \mathrm{BC}$ & $33.7 \mathrm{BC}$ \\
\hline & Combined & $72.9 \mathrm{ab}$ & $3.3 \mathrm{ab}$ & 12.8 & $35.0 \mathrm{a}$ & $69.1 \mathrm{ab}$ & $24.3 \mathrm{ab}$ \\
\hline \multirow{3}{*}{$\mathrm{M}_{2}$} & Drought & $58.3 \mathrm{C}$ & $3.2 \mathrm{BC}$ & $8.4 \mathrm{~B}$ & $20.9 \mathrm{CD}$ & $59.1 \mathrm{D}$ & $12.3 \mathrm{DE}$ \\
\hline & Nondrought & 84.6 AB & $3.7 \mathrm{~A}$ & $17.9 \mathrm{~A}$ & 46.7 AB & $68.9 \mathrm{BCD}$ & $31.0 \mathrm{C}$ \\
\hline & Combined & $71.4 \mathrm{ab}$ & $3.4 \mathrm{a}$ & 13.2 & $33.8 \mathrm{ab}$ & $64.0 \mathrm{~b}$ & $21.6 \mathrm{c}$ \\
\hline \multirow{3}{*}{$\mathrm{M}_{3}$} & Drought & $61.4 \mathrm{C}$ & $3.1 \mathrm{CD}$ & $7.8 \mathrm{BC}$ & 19.1 CD & $59.1 \mathrm{D}$ & $10.8 \mathrm{E}$ \\
\hline & Nondrought & $81.0 \mathrm{~B}$ & $3.9 \mathrm{~A}$ & $18.2 \mathrm{~A}$ & $44.1 \mathrm{~B}$ & $84.4 \mathrm{~A}$ & 34.7 B \\
\hline & Combined & $71.2 \mathrm{~b}$ & $3.5 \mathrm{a}$ & 13.0 & $31.6 \mathrm{~b}$ & $71.7 \mathrm{a}$ & $22.7 \mathrm{bc}$ \\
\hline \multirow{3}{*}{$\mathrm{M}_{4}$} & Drought & $59.9 \mathrm{C}$ & $2.6 \mathrm{E}$ & $5.9 \mathrm{C}$ & $17.9 \mathrm{D}$ & $59.8 \mathrm{D}$ & $10.6 \mathrm{E}$ \\
\hline & Nondrought & $89.8 \mathrm{~A}$ & $3.6 \mathrm{AB}$ & $19.3 \mathrm{~A}$ & $51.3 \mathrm{~A}$ & $78.9 \mathrm{AB}$ & $40.0 \mathrm{~A}$ \\
\hline & Combined & $74.9 \mathrm{a}$ & $3.1 \mathrm{~b}$ & 12.6 & $34.6 \mathrm{ab}$ & $69.3 \mathrm{ab}$ & $25.3 \mathrm{a}$ \\
\hline
\end{tabular}

Mean values sharing the same case letter do not differ significantly at P 0.05 . 
These results refer to the importance of environmental conditions during selection in early generations on genetic configuration in later generations.

In cowpea Cristina and Hall (1995) reported that, plant characters bearing desirable gene combinations are easily identified and selected at the early generations preferably at the $F_{1}$ before reaching homozygosity in the late generations. This in agreement with Aremu (2011) and Araujo and Coulman (2002).

Insignificant differences between mean values of $\mathrm{M}_{4}$ and $\mathrm{M}_{1}$ (25.3g and $24.3 \mathrm{~g}$, respectively) overall conditions indicated that selection for high seed yield genotypes is associated with a specific environment and its seed yield has high variability due to environment changes or selection high seed yield genotypes combined with high reduction under stress but, lower seed yield genotype under favorable conditions combined with low reduction. On contrary, Oosterom and Ceccarelli 1993 reported that selection for high yield environments for heading date and plant ideotype can be an efficient method of selection for yield of barley under stress, especially in early generations and an assumption of Banziger and Edmeades, 1997 superior genotypes under favorable condition will also be superior under stressed ones.

It can be seen from Table 4 the highest seed yield/plant was produced by Luz x Hassawi 3 and TW x Hassawi 2 selected by $\mathrm{M}_{4}$ under non-drought stress followed by and TW x Hassawi 2 selected by $\mathrm{M}_{3}$ and TW x Hassawi 3 selected by $\mathrm{M}_{1}$ indicating that important of genetic back ground of parents and responses of genotypes to selection methods under different conditions may be not controlled by one theoretic. Fikreselassie and Seboka (2012) reported that a yield response to different selection methods is dependent on gene-pool and selection site.

To compare the variation among crosses due to selection methods under stress and non-drought stress, estimation of variance components $\left(\sigma^{2} \mathrm{~g}\right.$, $\sigma^{2} \mathrm{ph}$,), phenotypic (PCV) and genotypic coefficient of variability (GCV), broad sense of heritability $\left(\mathrm{h}^{2}\right)$ and genetic advance are given in Table 5. The highest PCV and GCV values were recorded in no. of pods and while the lowest one was in plant height under both environments. The differences between phenotypic and genotypic coefficient of variability in no. of branches and seed yield/plant were higher than other traits indicating the role of environment on these traits.

Concerning selection methods, $\mathrm{M}_{3}$ and $\mathrm{M}_{4}$ under both conditions had highest PCV, GCV values may be due to the primarily origin under favorite conditions increased the variabilities and suggested that bulk selection under favorite conditions increased the phenotypic and genotypic variance, particularly under the same conditions. Nechifor et al., 2011 found that large differences between GCV\% and PCV\% were observed for the number of seeds, seed index and seed yield of common bean. Broad sense heritability had wide range among traits due to breeding methods and stress conditions. For seed yield/plant the highest $\mathrm{h}^{2}(0.97)$ recorded in $\mathrm{M}_{4}$ under non stress followed by $\mathrm{M}_{1}(0.89)$ under drought stress. This mean that $\mathrm{h}^{2}$ was higher for each selection method under conditions that breed for it. Indicating that, selection high yield alleles under specific condition may be combined with sensitive alleles to other condition. As average of the studied traits $h^{2}$ was higher under drought stress and the highest estimates (0.90) was observed by selection method $\mathbf{M}_{2}$. Solieman and Ragheb 2014 recorded high heritability reach to $99.8 \%$ for no. of pods/plant.

Table 4. Mean performance of the six faba bean crosses selected by four methods and evaluated under drought stress and non-drought stress conditions.

\begin{tabular}{|c|c|c|c|c|c|c|c|c|c|c|c|c|c|}
\hline \multirow{2}{*}{ Cross } & \multirow{2}{*}{ 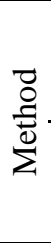 } & \multicolumn{2}{|c|}{$\begin{array}{l}\text { Plant height } \\
\text { (cm) }\end{array}$} & \multicolumn{2}{|c|}{$\begin{array}{l}\text { No. of } \\
\text { branches } \\
\text { /plant }\end{array}$} & \multicolumn{2}{|c|}{$\begin{array}{l}\text { No. of pods } \\
\text { /plant }\end{array}$} & \multicolumn{2}{|c|}{$\begin{array}{l}\text { No. of seeds } \\
\text { /plant }\end{array}$} & \multicolumn{2}{|c|}{$\begin{array}{l}100 \text { seed } \\
\text { weight }(\mathrm{g})\end{array}$} & \multicolumn{2}{|c|}{$\begin{array}{l}\text { Seed yield/ } \\
\text { plant (g) }\end{array}$} \\
\hline & & $\begin{array}{l}\text { Droug } \\
\text { ht }\end{array}$ & $\begin{array}{l}\text { Non- } \\
\text { drou } \\
\text { ght }\end{array}$ & $\begin{array}{l}\text { Drou } \\
\text { ght }\end{array}$ & $\begin{array}{l}\text { Non- } \\
\text { drou } \\
\text { ght }\end{array}$ & $\begin{array}{l}\text { Drou } \\
\text { ght }\end{array}$ & $\begin{array}{l}\text { Non- } \\
\text { drou } \\
\text { ght }\end{array}$ & $\begin{array}{l}\text { Drou } \\
\text { ght }\end{array}$ & $\begin{array}{l}\text { Non- } \\
\text { drou } \\
\text { ght }\end{array}$ & $\begin{array}{l}\text { Drou } \\
\text { ght }\end{array}$ & $\begin{array}{l}\text { Non- } \\
\text { drou } \\
\text { ght }\end{array}$ & $\begin{array}{l}\text { Drou } \\
\text { ght }\end{array}$ & $\begin{array}{l}\text { Non- } \\
\text { drou } \\
\text { ght }\end{array}$ \\
\hline \multirow{8}{*}{ 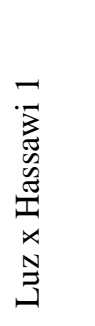 } & $\bar{M}$ & $62.1 \mathrm{I}-$ & 87.1 & $4.2 \mathrm{~A}-$ & 4.1 & 8.1 & 12.1 & 25.5 & 34.7 & 69.9 & 79.7 & 17.5 & 27.6 \\
\hline & 1 & $\mathrm{Q}$ & A-E & $E$ & A-E & K-P & G-P & L-S & $\mathrm{I}-\mathrm{O}$ & B-H & B-F & $\mathrm{J}-\mathrm{P}$ & E-J \\
\hline & $M$ & 531 & 81.6 & 3.5 & 3.5 & 9.4 I- & 10.2 & 22.6 & 31.5 & 54.4 & 78.3 & 12.2 & 25.0 \\
\hline & 2 & PQ & A-I & A-K & A-K & $\mathrm{P}$ & I-P & M-S & J-Q & E-H & B-F & NOP & F-L \\
\hline & $\bar{M}$ & 60.9 & 73.5 & 3.6 & 4.1 & 7.0 & 12.6 & 14.9 & 33.5 & 67.3 & 101. & 10.0 & 32.8 \\
\hline & 3 & $\mathrm{~J}-\mathrm{Q}$ & C-O & A-J & A-E & L-P & G-P & QRS & J-P & $\mathrm{C}-\mathrm{H}$ & $3 \mathrm{AB}$ & OP & C-G \\
\hline & $M$ & $56.4 \mathrm{~N}$ & 86.9 & 2.2 & 3.0 & & 19.4 & 13.0 & 46.8 & 60.8 & 81.9 & 8.0 & 38.0 \\
\hline & 4 & $-Q$ & A-E & H-K & B-K & 4.115 & $C-G$ & $\mathrm{RS}$ & C-K & D-H & $A-F$ & OP & B-E \\
\hline \multirow{4}{*}{$\begin{array}{l}\text { Luz X } \\
\text { Hassa } \\
\text { wi } 2\end{array}$} & $\bar{M}$ & $60.8 \mathrm{~K}$ & 96.5 & 3.0 & 3.7 & $8.7 \mathrm{~J}-$ & 14.8 & 29.5 & 41.2 & 65.6 & 91.5 & 19.4 & 37.2 \\
\hline & 1 & $-Q$ & $A B$ & B-K & A-H & $\mathrm{P}$ & D-M & K-R & E-L & C-H & A-D & $\mathrm{H}-\mathrm{O}$ & B-E \\
\hline & $\mathrm{M}$ & $65.0 \mathrm{G}$ & 96.9 & 3.6 & 2.8 & 11.2 & 13.5 & 26.0 & 35.8 & 60.7 & 75.0 & 15.5 & 27.0 \\
\hline & 2 & $-Q$ & $\mathrm{AB}$ & A-J & D-K & G-P & E-N & L-S & $\mathrm{H}-\mathrm{O}$ & D-H & B-G & K-P & E-K \\
\hline
\end{tabular}




\begin{tabular}{|c|c|c|c|c|c|c|c|c|c|c|c|c|c|}
\hline & \multicolumn{13}{|c|}{ Table 4. Cont. } \\
\hline & $\mathrm{M}$ & $64.9 \mathrm{G}$ & 87.0 & 4.3 & 4.5 & $9.1 \mathrm{I}-$ & 12.9 & 19.7 & 32.2 & 67.1 & 101. & 13.3 & 32.6 \\
\hline & 3 & $-Q$ & A-E & A-D & $\mathrm{AB}$ & $\mathrm{P}$ & $\mathrm{F}-\mathrm{O}$ & $\mathrm{N}-\mathrm{S}$ & $\mathrm{J}-\mathrm{Q}$ & $\mathrm{C}-\mathrm{H}$ & $2 \mathrm{AB}$ & M-P & $C-G$ \\
\hline & $\mathrm{M}$ & $74.9 \mathrm{C}$ & 96.8 & 4.1 & 2.8 & 7.1 & 15.5 & 19.9 & 43.9 & 67.4 & 81.1 & 13.5 & 35.6 \\
\hline & 4 & $-\mathrm{O}$ & $\mathrm{AB}$ & A-F & $\mathrm{D}-\mathrm{K}$ & L-P & D-K & $\mathrm{N}-\mathrm{S}$ & D-K & C-H & A-F & L-P & $\mathrm{C}-\mathrm{F}$ \\
\hline \multirow{8}{*}{$\begin{array}{l}\text { Luz x } \\
\text { Hassa } \\
\text { wi } 3\end{array}$} & $\mathrm{M}$ & $55.8 \mathrm{O}$ & 86.2 & \multirow{2}{*}{$2.0 \mathrm{~K}$} & 4.5 & 6.8 & 19.3 & 20.7 & 51.6 & 62.4 & 75.7 & 12.5 & 34.0 \\
\hline & 1 & PQ & A-E & & $\mathrm{AB}$ & M-P & C-G & $\mathrm{N}-\mathrm{S}$ & C-I & D-H & C-H & NOP & C-G \\
\hline & $\bar{M}$ & $\overline{59.3 \mathrm{M}}$ & 84.4 & 3.2 & 3.5 & 8.0 & 12.5 & 20.2 & 36.2 & 59.2 & 81.2 & 11.9 & 29.5 \\
\hline & & $-\mathrm{Q}$ & $A-G$ & B-K & A-K & K-P & G-P & $\mathrm{N}-\mathrm{S}$ & G-N & D-H & A-F & NOP & D-I \\
\hline & $\mathrm{M}$ & 56.5 & 78.8 & 2.1 & 3.9 & \multirow{2}{*}{$4.7 \mathrm{P}$} & 10.7 & 11.2 & 29.7 & 66.1 & 113. & \multirow{2}{*}{$7.5 \mathrm{P}$} & 33.8 \\
\hline & 3 & $\mathrm{~N}-\mathrm{Q}$ & B-M & IJK & A-G & & I-P & $\mathrm{S}$ & K-R & C-H & $7 \mathrm{~A}$ & & C-G \\
\hline & $\bar{M}$ & 49.2 & 82.3 & 2.2 & 3.2 & 4.8 & 17.3 & 15.5 & 53.3 & 55.7 & 97.9 & 8.5 & 52.1 \\
\hline & 4 & Q & A-H & $\mathrm{H}-\mathrm{K}$ & B-K & $\mathrm{OP}$ & D-I & QRS & B-G & E-H & $\mathrm{ABC}$ & $\mathrm{OP}$ & A \\
\hline \multirow{8}{*}{$\begin{array}{l}\text { TW x } \\
\text { Hassa } \\
\text { wi } 1\end{array}$} & $\mathrm{M}$ & 60.0 & 91.8 & 2.4 & 3.9 & $9.5 \mathrm{I}-$ & 15.1 & 25.5 & 47.3 & 50.2 & 67.8 & 12.9 & 31.0 \\
\hline & 1 & L-Q & $\mathrm{ABC}$ & G-K & $A-G$ & $\mathrm{P}$ & D-L & L-S & C-J & FGH & B-H & M-P & C-H \\
\hline & $\mathrm{M}$ & \begin{tabular}{ll|}
65.8 \\
\end{tabular} & 71.3 & 4.3 & 5.0 & 8.3 & 26.8 & 21.0 & 54.2 & 66.9 & 63.4 & 14.1 & 34.0 \\
\hline & 2 & F-Q & D-P & A-D & A & K-P & BC & N-S & B-F & C-H & D-H & L-P & C-G \\
\hline & $\bar{M}$ & $\begin{array}{l}67.8 \\
\end{array}$ & 91.0 & 2.7 & 3.1 & 8.3 & 16.6 & 21.5 & 45.5 & 60.4 & 53.6 & 12.8 & 24.4 \\
\hline & 3 & E-Q & A-D & E-K & B-K & K-P & D-J & N-S & D-K & D-H & FGH & M-P & F-M \\
\hline & $\mathrm{M}$ & 64.0 & 100. & 3.0 & 4.5 & 5.5 & 13.5 & 18.8 & 38.8 & 56.0 & 59.5 & 10.2 & 23.1 \\
\hline & 4 & H-Q & $1 \mathrm{~A}$ & B-K & $\mathrm{ABC}$ & NOP & E-N & $\mathrm{O}-\mathrm{S}$ & F-M & E-H & D-H & $\mathrm{OP}$ & G-N \\
\hline \multirow{8}{*}{$\begin{array}{l}\text { TW } x \\
\text { Hassa } \\
\text { wi } 2\end{array}$} & $\bar{M}$ & 59.7 & 79.5 & \multirow{2}{*}{$2.0 \mathrm{~K}$} & 4.0 & 7.5 & 21.7 & 21.1 & 47.3 & 87.8 & 65.4 & 18.2 & 30.8 \\
\hline & 1 & L-Q & B-L & & A-F & K-P & CDE & $\mathrm{N}-\mathrm{S}$ & C-J & A-E & C-H & I-P & C-H \\
\hline & \multirow[t]{2}{*}{ M } & 53.6 & 88.2 & \multirow{2}{*}{$\begin{array}{l}2.5 \\
\text { F-K }\end{array}$} & 4.3 & 6.4 & 22.8 & 15.9 & 69.9 & 55.5 & $\begin{array}{l}53.7 \\
\end{array}$ & 8.9 & 37.7 \\
\hline & & PQ & A-D & & A-D & NOP & $\mathrm{CD}$ & QRS & $\mathrm{AB}$ & E-H & FGH & $\mathrm{OP}$ & B-E \\
\hline & \multirow[t]{2}{*}{$\bar{M}$} & 50.7 & 80.0 & \multirow{2}{*}{$\begin{array}{l}3.0 \\
\text { B-K }\end{array}$} & 4.5 & 11.0 & 35.6 & 31.0 & 63.9 & 37.9 & 75.2 & 11.7 & 48.0 \\
\hline & & Q & B-K & & $\mathrm{ABC}$ & H-P & A & $\mathrm{J}-\mathrm{Q}$ & $\mathrm{ABC}$ & $\mathrm{H}$ & B-G & NOP & $\mathrm{AB}$ \\
\hline & $\mathrm{M}$ & 51.5 & 80.7 & \multirow{2}{*}{$2.0 \mathrm{~K}$} & 4.4 & 5.5 & 31.0 & 19.0 & $\begin{array}{ll}77.3 \\
\end{array}$ & $\begin{array}{l}76.3 \\
\end{array}$ & 64.9 & 14.5 & 50.1 \\
\hline & 4 & $\mathrm{Q}$ & A-J & & A-D & NOP & $\mathrm{AB}$ & $\mathrm{N}-\mathrm{S}$ & A & B-F & C-H & L-P & A \\
\hline \multirow{8}{*}{$\begin{array}{l}\text { Tw x } \\
\text { Hassa } \\
\text { wi } 3\end{array}$} & $\mathrm{M}$ & 50.5 & 84.4 & 2.5 & 3.4 & $8.5 \mathrm{~J}-$ & 21.5 & 18.5 & 57.2 & 51.3 & 72.5 & 9.5 & 41.5 \\
\hline & & $\mathrm{Q}$ & $A-G$ & F-K & A-K & $\mathrm{P}$ & CDE & O-S & B-E & FGH & B-G & $\mathrm{OP}$ & $\mathrm{ABC}$ \\
\hline & $\mathrm{M}$ & 52.7 & 85.4 & 2.1 & 2.9 & 6.9 & 21.5 & 19.4 & 52.6 & 57.8 & 61.9 & 11.2 & 32.6 \\
\hline & 2 & $\mathrm{PQ}$ & $A-F$ & JK & C-K & M-P & $\mathrm{CDE}$ & N-S & B-H & E-H & D-H & $\mathrm{OP}$ & C-G \\
\hline & $\mathrm{M}$ & 67.5 & 75.9 & 2.9 & 3.4 & 6.5 & 21.1 & 16.6 & 59.6 & 55.6 & 61.6 & 9.2 & 36.8 \\
\hline & 3 & E-Q & $\mathrm{C}-\mathrm{N}$ & C-K & B-K & NOP & C-F & P-S & $\mathrm{BCD}$ & E-H & D-H & $\mathrm{OP}$ & B-E \\
\hline & $\mathrm{M}$ & 63.3 & 92.3 & 2.2 & 3.7 & 7.6 & 18.9 & 21.4 & 47.9 & 42.4 & 88.0 & 8.8 & 40.6 \\
\hline & 4 & H-Q & $\mathrm{ABC}$ & H-K & A-I & K-P & C-H & $\mathrm{N}-\mathrm{S}$ & C-J & $\mathrm{GH}$ & A-E & $\mathrm{OP}$ & A-D \\
\hline
\end{tabular}

Mean values sharing the same case letter do not differ significantly at $\mathrm{P} 0.05$.

Table 5. Mean Squares, genotypic and phenotypic coefficient of variations and heritability of crosses under stress and non-drought stress conditions.

\begin{tabular}{|c|c|c|c|c|c|c|c|c|}
\hline & \multicolumn{8}{|c|}{ Plant height } \\
\hline & \multicolumn{4}{|c|}{ Drought stress } & \multicolumn{4}{|c|}{ Non drought stress } \\
\hline & $\mathrm{M}_{1}$ & $\mathrm{M}_{2}$ & $\mathrm{M}_{3}$ & $\mathrm{M}_{4}$ & $\mathrm{M}_{1}$ & $\mathrm{M}_{2}$ & $\mathrm{M}_{3}$ & $\mathrm{M}_{4}$ \\
\hline MScross & $55.8 \mathrm{~ns}$ & $109.6 * *$ & $136.8 \mathrm{~ns}$ & $270.3 * *$ & $105.5^{*}$ & $210.6 * *$ & $134.3^{*}$ & $184.3 \mathrm{~ns}$ \\
\hline $\mathrm{h}^{2}$ & & 0.86 & & 0.92 & 0.76 & 0.85 & 0.81 & \\
\hline GCV \% & & 9.62 & & 15.23 & 5.91 & 9.14 & 7.41 & \\
\hline \multirow[t]{4}{*}{$\mathrm{PCV} \%$} & & 10.36 & & 15.85 & 6.77 & 9.90 & 8.26 & \\
\hline & \multicolumn{8}{|c|}{ No. of branches/plant } \\
\hline & \multicolumn{4}{|c|}{ Drought stress } & \multicolumn{4}{|c|}{ Non drought stress } \\
\hline & $\mathrm{M}_{1}$ & $\mathrm{M}_{2}$ & $\mathrm{M}_{3}$ & $\mathrm{M}_{4}$ & $\mathrm{M}_{1}$ & $\mathrm{M}_{2}$ & $\mathrm{M}_{3}$ & $\mathrm{M}_{4}$ \\
\hline MScross & $2.01 * *$ & $1.97 * *$ & $1.7^{*}$ & $1.89 *$ & $0.41 \mathrm{~ns}$ & $2.15^{* *}$ & $1.0 *$ & $1.47 *$ \\
\hline$h^{2}$ & 0.87 & 0.91 & 0.79 & 0.80 & & 0.95 & 0.78 & 0.82 \\
\hline GCV \% & 28.49 & 23.19 & 21.62 & 26.29 & & 22.51 & 13.02 & 17.81 \\
\hline \multirow[t]{4}{*}{$\mathrm{PCV} \%$} & 30.57 & 24.34 & 24.40 & 29.47 & & 23.14 & 14.78 & 19.65 \\
\hline & \multicolumn{8}{|c|}{ No. of pods/plant } \\
\hline & \multicolumn{4}{|c|}{ Drought stress } & \multicolumn{4}{|c|}{ Non drought stress } \\
\hline & $\mathrm{M}_{1}$ & $\mathrm{M}_{2}$ & $\mathrm{M}_{3}$ & $\mathrm{M}_{4}$ & $\mathrm{M}_{1}$ & $\mathrm{M}_{2}$ & $\mathrm{M}_{3}$ & $\mathrm{M}_{4}$ \\
\hline
\end{tabular}




\begin{tabular}{|c|c|c|c|c|c|c|c|c|}
\hline MScross & $2.7 \mathrm{~ns}$ & $9.2 * *$ & $14.6 * *$ & $4.4^{*}$ & $78.2 * *$ & $67.16 * *$ & $157.0 * *$ & $108.3 * *$ \\
\hline $\mathrm{h}^{2}$ & & 0.89 & 0.90 & 0.74 & 0.91 & 0.94 & 0.92 & 0.95 \\
\hline $\mathrm{GCV} \%$ & & 20.28 & 26.87 & 17.97 & 22.43 & 23.06 & 32.44 & 26.52 \\
\hline \multirow[t]{4}{*}{ PCV \% } & & 21.55 & 28.40 & 20.92 & 23.47 & 23.78 & 33.80 & 27.15 \\
\hline & \multicolumn{8}{|c|}{ No. of seeds/plant } \\
\hline & \multicolumn{4}{|c|}{ Drought stress } & \multicolumn{4}{|c|}{ Non drought stress } \\
\hline & $\mathrm{M}_{1}$ & $\mathrm{M}_{2}$ & $\mathrm{M}_{3}$ & $\mathrm{M}_{4}$ & $\mathrm{M}_{1}$ & $\mathrm{M}_{2}$ & $\mathrm{M}_{3}$ & $\mathrm{M}_{4}$ \\
\hline MScross & $49.7 \mathrm{~ns}$ & $33.6 \mathrm{~ns}$ & $140.5 * *$ & $28.9 \mathrm{~ns}$ & $209.5 *$ & $370.5 * *$ & $402.0 * *$ & $553.5 * *$ \\
\hline $\mathrm{h}^{2}$ & 0.64 & & 0.93 & & 0.76 & 0.93 & 0.94 & 0.97 \\
\hline GCV \% & 13.86 & & 34.40 & & 13.60 & 21.12 & 23.64 & 23.36 \\
\hline \multirow[t]{4}{*}{$\mathrm{PCV} \%$} & 17.35 & & 35.75 & & 15.57 & 21.90 & 24.43 & 23.72 \\
\hline & \multicolumn{8}{|c|}{ 100seed weight } \\
\hline & \multicolumn{4}{|c|}{ Drought stress } & \multicolumn{4}{|c|}{ Non drought stress } \\
\hline & $\mathrm{M}_{1}$ & $\mathrm{M}_{2}$ & $\mathrm{M}_{3}$ & $\mathrm{M}_{4}$ & $\mathrm{M}_{1}$ & $\mathrm{M}_{2}$ & $\mathrm{M}_{3}$ & $\mathrm{M}_{4}$ \\
\hline MScross & $572.7 * *$ & $59.6 \mathrm{~ns}$ & $387.3 * *$ & $399.9 *$ & $241.2 * *$ & $61.9 \mathrm{~ns}$ & $439.5^{*}$ & $345.4 *$ \\
\hline $\mathrm{h}^{2}$ & 0.87 & & 0.94 & 0.75 & 0.85 & & 0.80 & 0.77 \\
\hline $\mathrm{GCV} \%$ & 19.95 & & 18.64 & 16.79 & 13.04 & & 15.20 & 13.45 \\
\hline \multirow[t]{4}{*}{ PCV \% } & 21.42 & & 19.24 & 19.33 & 14.11 & & 16.96 & 15.29 \\
\hline & \multicolumn{8}{|c|}{ Seed yield/plant } \\
\hline & \multicolumn{4}{|c|}{ Drought stress } & \multicolumn{4}{|c|}{ Non drought stress } \\
\hline & $\mathrm{M}_{1}$ & $\mathrm{M}_{2}$ & $\mathrm{M}_{3}$ & $\mathrm{M}_{4}$ & $\mathrm{M}_{1}$ & $\mathrm{M}_{2}$ & $\mathrm{M}_{3}$ & $\mathrm{M}_{4}$ \\
\hline MScross & $45.9 * *$ & $16.2 \mathrm{~ns}$ & $15.3^{*}$ & $23.0 * *$ & $76.2 *$ & $71.0 \mathrm{~ns}$ & $209.0^{*}$ & $334.6 * *$ \\
\hline $\mathrm{h}^{2}$ & 0.89 & & 0.73 & 0.84 & 0.82 & & 0.82 & 0.94 \\
\hline $\mathrm{GCV} \%$ & 24.69 & & 17.93 & 24.13 & 13.53 & & 22.46 & 25.11 \\
\hline PCV \% & 26.11 & & 20.97 & 26.35 & 14.98 & & 24.88 & 26.46 \\
\hline
\end{tabular}

\section{References}

Allard, R.W. (1988) Genetic changes associated with the evolution of adaptedness in cultivated plants and their wild progenitors. Journal of Heredity 79, 225-238.

Allard, R.W. (1999): Principles of plant breeding. $2^{\text {nd }}$ edn.New York, John Wiley \& Sons.

Abdellatif, K.F., E. A. El Absawy and A. M. Zakaria (2012). Drought stress tolerance of faba bean as studied by morphological traits and seed storage protein pattern. Journal of Plant Studies; Vol. 1, No. 2:47-54.

Amede, T. and S. Schubert (2003).Mechanisms of drought resistance in seed legumes. I. Osmotic adjustment. Ethiop. J. Sci, 26, 37-46

Ammar, M. H., F. Anwar, E. H. El-Harty, H. M. Migdadi, S. M. Abdel-Khalik, S. A. Al-Faifi, M. Farooq and S. S. Alghamdi (2014). Physiological and Yield Responses of Faba bean (Vicia faba L.) to Drought Stress in Managed and Open Field. Environments. J.Agro. Crop Sci.,:1-8

Araujo, M.R.A. and B.E.Coulman, (2002).Genetic variation, heritability and progeny testing in meadow bromegrass. Plant Breeding, (121):417424.

Aremu, C.O (2011). Trait Response to EarlyGeneration Selection using a common parent in two crosses of Cowpea (Vigna unguiculata) for humid environment performance. Adv. Appl. Sci. Res., 2011, 2(6):155-160
Banziger, M. and G.O. Edmeades, (1997). Predicted productivity gains from breeding maize under stressed vs. non-stressed conditions. In: J.K. Ransom, A.F.E. Palmer, B.T. Zambezi, Z.O. Mduruma, S.R. Waddington, K.V. Pixley\& D.C. Jewell (Eds.), Maize Productivity Gains Through Research and Technology Dissemination, pp. 136-140. Proc 5th Eastern and Southern Africa Regional Maize Conference, held in Arusha, Tanzania, 3-7 June 1996. Addis Abeba, Ethiopia: CIMMYT.

Blum, A. (1984) Methods of selection for plant tolerance to environmental stresses. In: Selection in mutation breeding. Proceedings of the Consultants' Meeting Vienna, 21-25 June 1982. : 85-96. International Atomic Energy Agency, Vienna, Austria

Borlaug, N.E. and C. R. Dowswell (2005). Feeding a world of ten billion people: a $21^{\text {st }} \quad$ century challenge. In: Tuberosa, R., Phillips, R.L., Gale, M.D. (Eds.), In the Wake of the Double Helix: From the Green Revolution to the Gene Revolution, 27-31 May 2003, Bologna, Italy. Avenue Media, Bologna, Italy.

Ceccarelli, S., S. Grando and J. Hamblin (1992). Relationship between barley-grain yield measured in low yielding and high yielding environments. Euphytica, V1., 64 No. 1-2 :49-58.

Cristina A and E. Hall (1995). Heritability of carbon isotope discrimination and correlations with earliness in cowpea. Crop Sci,., 35,3, 673- 678. 
Dawson J.C. andI. Goldringer (2012).Breeding for genetically diverse populations: variety mixtures and evolutionary populations. Organic Crop Breeding: 77-98.

Fikreselassie, M. and H. Seboka (2012).Genetic variability on seed yield and related traits of elite faba bean (Vicia faba L.) genotypes. Pakistan Journal of Biological Sciences 15 (8): 380-385

Fox, P. N., J. Crossa and I. Ramagosa (1997).Multi environment testing and genotype_/environment interaction. In: Kempton, R. A. and Fox, P. N. (eds), Statistical methods for plant variety evaluation. Chapman \& Hall, p. 117_/138.

Frahm, M. A., J.C. Rosas, N.Mayek-P'erez, E.L'opez-Salinas,J. A. Acosta-Gallegos and J. D. Kelly(2004). Breeding beans for resistance to terminal drought in the lowland tropics. Euphytica 136: 223-232.

Grashoff, C. (1990). Effect of pattern of water supply on Vicia faba L. I. dry matter partitioning and yield variability. Netherlands Journal of Agricultural Science 38 :21-44.

Keneni, G., B. Asmamaw and M. Jarso (2001).Efficiency of drained selection environments for improving grain yield in faba bean under undrained target environments on vertisol.Euphytica 122: 279-285.

Khan, H. R., W. Link, T. J. Hocking and F. L. Stoddard (2007).Evaluation of physiological traits for improving drought tolerance in faba bean (Vicia faba L.). Plant Soil, 292:205-217.

Khan, H.R., J.G. Paull, K.H.M. Siddique and F.L. Stoddard (2010). Faba bean breeding for drought-affected environments: A physiological and agronomic perspective. Field Crops Research, (115):279-286

Lande, R. (2009). Adaptation to an extraordinary environment by evolution of phenotypic plasticity and genetic assimilation. Journal of Evolutionary Biology 22: 1435-1446.

Ludlow, M.M. and R.C. Muchow (1990). A critical evaluation of traits for improving crop yields in water-limited environments. Adv. Agron. 43, 107-153.

Marsh, T.J (1996) The 1995 UK drought — a signal of cli- matic instability? ProcInstCiv Eng.,Water Marit Energy 118:189-195

Mwanamwenge, J., S. P. Loss, K. H. M. Siddique and P. S. Cocks (1998). Growth, seed yield and water use of faba bean (Vicia faba L.) in a short-season Mediterranean-type environment. Australian Journal of Experimental Agriculture, 38:171-80

Nechifor, B., R.Filimon and L.Szilagyi (2011). Genetic variability, heritability and expected genetic advance as indices for yield and yield components selection in common bean (Phaseolus vulgaris L.). University of Agronomic Sciences and Veterinary Medicine of Bucharest, 5:332-337.

Oosterom, E. J. and S. Ceccarelli (1993). Indirect selection for grain yield of barley in harsh Mediterranean environments. Crop Sci., (33) No. 6, :1127-113

Sharma, J.R. (1998). Statistical and biometrical techniques in plant breeding. New Age International Publication, New Delhi. p. 432

Singh, S.P. (1995). Selection for water tolerance in interracial populations of common bean. Crop Science 35:118-124.

Singh, R.K. and B.D. Chaudhary (1985): Biometrical methods in quantitative genetic analysis. Kalyani Publisher, New Delhi, India.

Solieman, T.H.I. and E.I.M. Ragheb (2014).Two selection methods and estimation of some important genetic parameters in broad bean (Vicia faba L.).Asian J. Crop Sci., 6 (1): 38-48.

Stoddard, F.L., C. Balko, W. Erskine, H.R. Khan, W. Link and A. Sarker(2006). Screening techniques and sources of resistance to abiotic stresses in cool-season food legumes. Euphytica 147, 167-186.

Steel, R. D. G., J. H. Torrie and D. A. Dickey (1997).Principles and procedures of statistics. A

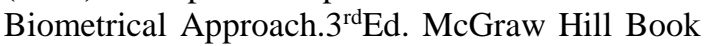
Co. Inc. New York.

Terzopoulos, P.J., P.J. Kaltsikes andP.J. Bebeli (2008). Determining the sources of heterogeneity in Greek faba bean local populations. Field Crops Res., 105:124-130.

Turner, N.C., G.C. Wright and K.H.M. Siddique (2001). Adaptation of grain legumes (pulses) to water-limited environments. Adv. Agron. 71, 193-271.

Yahia, Y, A.Guetat, W.Elfalleh, A.Ferchichi, H.Yahia and M.Loumerem (2012) Analysis of agro-morphological diversity of southern Tunisia faba bean (Vicia faba L.) germplasm. African Journal of Biotechnology V. 11(56):11913-11924. 


\title{
انتخاب بعض التراكيب الوراثية فى الفول البلاي الانعزالية في بيئات متضادة
}

\author{
ايهاب حلمى الحارتى 1 \\ 1- قسم بحوث المحاصيل البقولية - معهد بحوث المحاصيل الحقلية- مركز البحوث الزارعية.
}

2- وحدة بحوث المحاصيل البقولية ، قسم الانتاج النباتي ، كلية علوم التغذية والزراعة ،جامعة الملك سعود ,الرياض ،المممكة العربية السعودية

\section{الملخص العربي}

اجريت طريقة الانتخاب الاجمالي في ستة هجن من الفول البلدي اثثاء الجيل الثالث والرابع تحت كلا من ظروف الجفاف وعدم الجفاف. تكونت اربعة طرق (M1 نمت تحت ظروف الجفاف في كل من الجيل الثالث والرابع وM2 نمت تحت ظروف الجفاف في الجيل الثالث

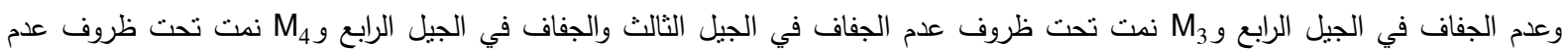
الجفاف في كل من الجيل الثالث والرابع) من كل هجين في الجيل الخامس وتم التقييم في تجربتين حقليتين (تحت ظروف الجفاف وعدم الجفاف). زرعت التجارب بنظام القطع المنشقة وكانت الهجن في القطع الرئيسية وطرق التربية في القطع المنشقة. كانت الاختلافات عالية المعنوية بين كل فل فئن

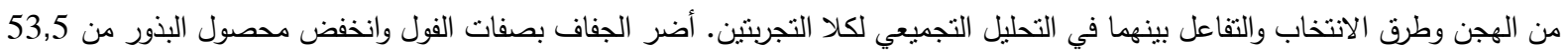
الي 74,4\% من تحت ظروف الجفاف انتجت طريقة الانتخاب M1 اعلي محصول بذور وتميزت هجن حساوي 2 على صنفين لوز وتربل ويت

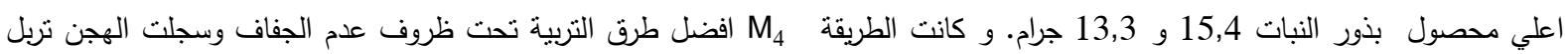
ويت في حساوي 2 وتربل ويت في حساوي 3 ولوز في حساوي 3 اعلي محصول بذور 41,7 و37,9 و 37.3 جرام علي النوالي. اقترحت القيم العالية لمعامل التباين الوراثي والمظهري لطريقة M4 تحت ظروف عدم الجفاف ان الانتخاب التجمعي ادي الي زيادة التباين الوراثي والمظهري

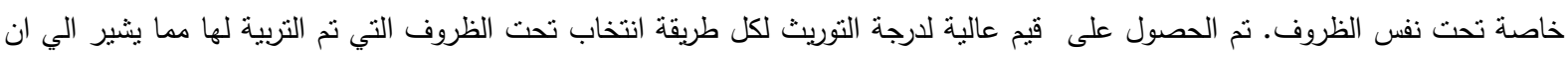

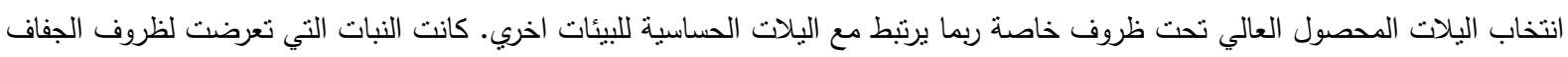

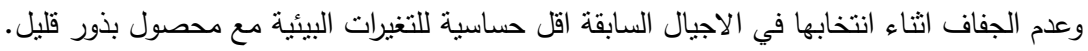

